\title{
SPACE CONFIGURATION AS AN ADAPTATION ELEMENT OF MADURESE MIGRANT URBAN SETTLEMENTS IN MALANG
}

\author{
Damayanti ASIKIN (D) ${ }^{1^{*}}$, ANTARIKSA ${ }^{1}$, Lisa Dwi WULANDARI ${ }^{1}$, Wara Indira RUKMI ${ }^{2}$ \\ ${ }^{1}$ Architecture Department, Faculty of Engineering, Brawijaya University, Malang 65145, Indonesia \\ ${ }^{2}$ Urban and Regional Planning, Faculty of Engineering, Brawijaya University, Malang 65145, Indonesia
}

Received 13 November 2018; accepted 19 December 2019

\begin{abstract}
Humans interacting with their physical and social environments always try to adapt individually or in groups. In the adaptation process, a space dynamic will occur and cause space changes. Adaptation elements include the physical environment, socio-cultural environment, and behavior. Interaction among the adaptation elements will form changes to space configuration. Kotalama is the largest Madurese migrant settlement in Malang and was established in the 1950s. Research on space configuration was conducted to study the adaptation elements in the interaction process of the migrants and their environment. The research used a qualitative, descriptive method and inductive analysis to gain insights on the relationship to dwellings on Madura Island. Data were collected through observations of dwelling space configuration. In addition, in-depth interviews with key informants were held. The results show that the space configuration of dwellings in Kotalama contain elements of adaptation and interaction between the migrants and their environment. These elements relate to Madurese ethnic identity, which are influenced by local topographical factors and limited by the size of the settlement area.
\end{abstract}

Keywords: space configuration, adaptation elements, Madurese migrants, urban settlement, Malang.

\section{Introduction}

When interacting with social and physical environments, human beings always try to adapt to their surroundings, individually and collectively, searching for a balance. The main elements of human and environmental adaptation are the physical environment, socio-cultural environment, and behavior (Berry, 2005; Schultz, 2009; Scannell \& Gifford, 2010). Each element is fluid and dynamic with any change in one, affecting the other two. Interaction among elements will result in space or configuration change (Levy-Leboyer, 1982). There are three causal factors of space change: The individual interaction with the space; the social interaction with the space, and knowledge of the architectural forms. Space is a place to do activities such as cooking, take care of children, etc. and a place to circulate. The human desire to live together will establish the space they need. In addition, time and necessity play a dynamic role (Smith, 1990) which leads to space change. This space will be marked and maintained as distinct from the space of other neighboring properties.

Space configuration can be seen as a part of a spatial culture, which can be viewed as a part of an individual's cultural heritage. Therefore, spatial configuration or structure is related to social rules and how the space users interact with each other. Place experience is an important foundation to manage human adaptation, and the sense of place has functioned as a reference to understand changes in the environment. A specific emotional relationship to a place correlates with that place, its memory, preferences, and recognition of a certain level of symbolic dimension. It encourages appreciation toward the memory of place or spirit of place in the human mind (Bott, Cantrill, \& Myers, 2003).

The human and environmental adaptation concept has three aspects. The behavioral, functional and structural aspects. The functional aspect reflects on the physical space of the environment (Kusliansjah, 2015), and the structural aspect occurs on temporal, spatial, social, and political scales (Reyes-García et al., 2016). During the adaptation process, humans frequently create the spatial structural change of their settlement (Kabir, 2012). This may be done by adding more rooms or developing the family's shared room by providing furniture or other elements (Reynoso et al., 2016).

*Corresponding author. E-mail: dama_asikin@ub.ac.id 
Cultural identity has an influence on the process of adaption which helps people to develop a sense of cultural space (Chen \& Pan, 2002). In order to keep the cultural integrity, people need to keep their cultural identity. This involves the positioning of individuals or others on a cultural map. Therefore, it involves the relationship between an individual, themselves and their community. The system of values, characters, and habits/traditions in their place of origin have an influence on the migrant in their new location. That all activities of the migrant will always orient to their place of origin.

The Madurese migrant community is the largest population in Malang (Ubaidilah, 2014). The Madurese culture will, therefore, become a distinctive factor of self-identity and reference in social interaction with local ethnicity (Wiyata, 2013). The Madurese migrants who live in the eastern area of the East Java region, are homogeneous, live in a group, and their lives are not the same as their place of origin (Syamsudin, 2007). Several studies have shown showed that with the passing of time, changes have occurred to several physical elements of the Madurese migrant's settlement while others have been preserved (Asikin et al., 2017; Ridjal, 2014). The changes recorded appear seem to have been influenced by culture and show a progression toward similar uses of space to that of a typical Madurese dwelling found in their home country.

This study investigates whether the configuration of dwelling space in a Madurese migrant settlement is the adaptation element in the interaction process of settlement. Observations are made on the residential units which constitute the space used for their activities and descriptions of social and cultural activities are used as data to be examined.

\section{Methods}

This study can be described as qualitative primary research which was conducted to find out the space configuration as an adaptation element in Madurese migrant urban settlements. Data was collected using observations and indepth interviews to examine if the resulting space configuration, was due to an adaptation process. A snowball approach was used to identify possible interviewees. The first person to be interviewed was the grandchild of one of the first Madurese migrants to settle in the Kotalama Malang settlement. During the in-depth interview, a further person was nominated to begin the snowball process.

This research used a descriptive, qualitative method using inductive analysis (Muhadjir, 1992; Moleong, 2016). The data were collected using semi-structured interviews with open questions. Written observation of the space configuration of their dwelling was also used. The observed objects were the dwelling units of the Madurese migrants in the micro-scale, where the dwelling is the smallest spatial unit in the settlement area that becomes the personal space of the family. Thirty-three dwellings are described as their space configuration. The data analyzed with reference to other studies on the Madurese community on Madura Island.

\section{The Madurese Migrant settlement of Kotalama}

Since the 1950s, Malang city has been one of the major economic migration destinations of the Madurese community from Bangkalan town (Jonge, 1989). However, migrants now come from other towns such as Pamekasan, Sampang and Sumenep (Ubaidillah, 2014; Ma’arif, 2015). Kotalama is the biggest of Madurese migrant settlements in Malang (Figure 1,2). The migrants' efforts to adapt or adjust their spatial needs to the existing resources in their settlement leads to a process of finding the balance between people and their environment. As discussed in the literature review, this process always leads to changes in space or space dynamics, which are seen as flexible and dynamic (Levy-Leboyer, 1982).

The community's interaction with the built environment in the cultural context can be viewed from a traditional perspective which includes kinship patterns and the traditional use of cultural space which are all based around traditional activities and the formality or informality of social activities (Jenkins, 1997). In reviewing the literature, kinship, religion, and the language used to communicate with the community in daily life, become the identity markers of the community and culture of the Madurese (Wiyata, 2013). This was also found to be the case at the Kotalama settlement. Furthermore, although surrounded by the majority of the population who speak Javanese, the

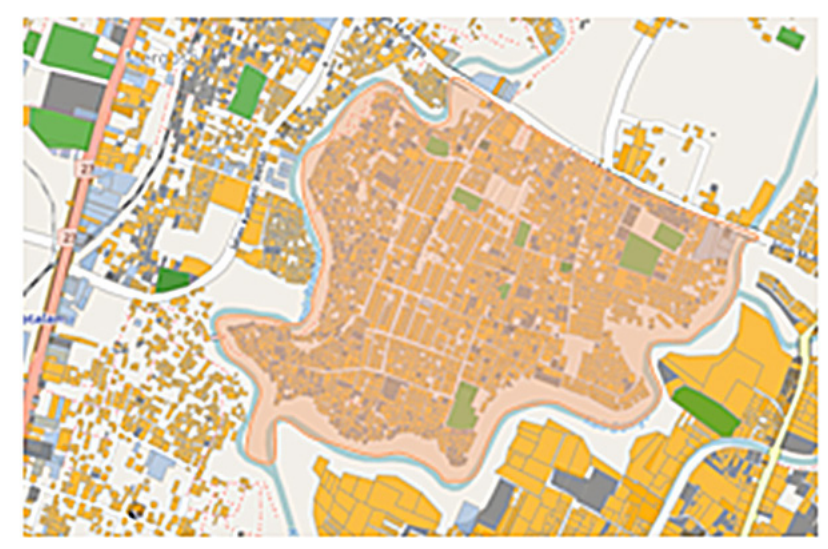

Figure 1. The area of Malang Kotalama settlement (source: Asikin et al., 2017)

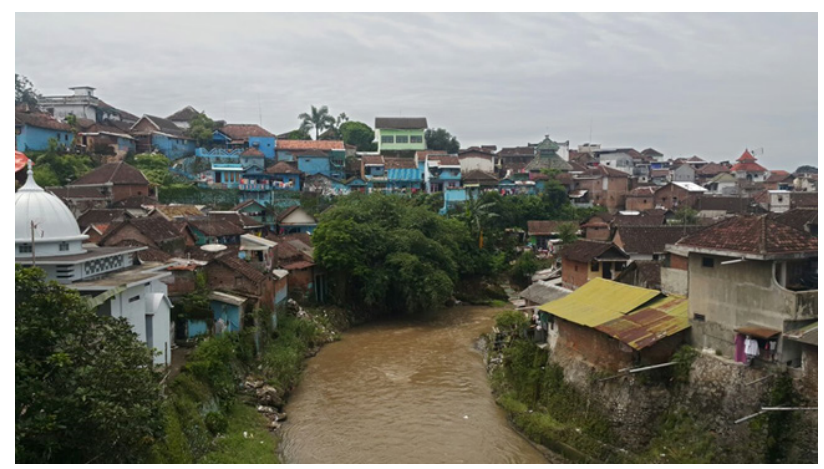

Figure 2. The Malang Kotalama settlement (source: filed survey, 2018) 
migrants still use Madurese to communicate with their community or speak Javanese using a Madurese accent. It also appears that the ability of the Madurese migrants to understand Javanese is one of their adaptive strategies to help with integration with the host community.

\section{The dwelling as a result adaptation process of humans interaction with their environment}

A dwelling is defined as one of the spatial forms of an artificial environment that accommodates people's activities (Amorim \& Loureiro, 2007). According to them, space is an integral part of socio-morphology and functions in accordance with the principles of social reproduction. Houses in Kotalama are generally used as dwelling for homemakers and not as a place to work, as the men usually work outside the settlement. A similar arrangement is found in traditional Madurese communities, where houses are places for women (Pangarsa, Tjahjono, \& Pamungkas, 1994; Tulistyantoro, 2005). This is influenced by its tegal ecology. Tegal is drylands that are cultivated or non-irrigated fields, which form the topography of Madura Island (Ma'arif, 2015). Few differences are found between the way people live in Kotalama and traditional Madura settlements. For example, houses laid out in a tanean lanjheng pattern in Madura and used by women and children. Men used the space outside of the house such as langgar (a place to pray) and place to work. Although the majority of space in a house in Kotalama is intended for use by women and men work outside the settlement for most of the day, then use the house after work.

Previous research has established that the primary function of the houses in the Kotalama settlement is as a dwelling (Asikin, 1996). However, some dwellings also function as a place of business for women. This is due to different topographical conditions of the settlement, which may not enable the migrant to make a living as in their origin places. A study conducted by Susanto (2008) has shown that different living patterns ban be caused by the livelihood factor, and limited land use for settlement.

In Madura, the parents endeavor to build houses for their children in close proximity, even though they may not be in the same cluster of houses as the tanean lanjheng pattern. Tanean lanjheng is from Madurese word means "a long yard”. This is a traditional pattern of dwelling where houses surround a long yard and belong to one nuclear family consisting of a father, mother, and children. This traditional pattern is a distinctive feature of Madura architecture which relates to the values and close kinship system of the community (Susanto, 2008; Taufiqurrahman, 2007; Mukhlisah, Antariksa, \& Wijayanto, 2011; Dewi, Antariksa, \& Surjono, 2008). However, local conditions, the environment and the size and nature of the family, has created a different pattern of settlement in Kotalama. If it is possible, a parent will try to get closer to their children, but this is no longer considered necessary as it was with the traditional house layout of tanean lanjheng.
In addition, the interaction pattern in Kotalama is not completely similar to traditional settlements Madura which also forms a social space. This may be due to differences in kinship relationships and lifestyles. Each person has their own personal space in Kotalama which is formed within the unit of the dwelling, while in Madura, it is arranged among several units of building (Figure 3 ). However, there are similarities in the form of a single space which is then spatially divided. In general, these differences in the construction of personal space may be due to different dwelling dimensions and related to limited land use.

The study of the spatial adaptation in the Kotalama settlement by Asikin et al. (2017) showed spatial dynamics that occurred in the micro-scale and mesoscale, are considered elements of resilience in the adaptation process. The dwelling unit is more individualized than the traditional Madurese pattern (tanean lanjheng), which is usually built-in clusters based on kinship bonds (Asikin, 1996). However, the choice of where to put dwellings is more broadly based on people's place of origin, and not so closely based on their kinship relationships. The basic pattern of the spatial formation of the Madurese migrant dwelling is a single space that is so-called mubeng kandhang which comes from the Javanese language that refers to space which only has a buttress edge, without a full partition. This pattern is affected by the economic status of the owner, their knowledge Madurese buildings, and relates to the claim of the area to owned in that environment.

The layout of a typical dwelling unit at Kotalama usually comprises of space to receive guests (amper), bedroom (kamar) and kitchen (pawon) (Figure 4). The house
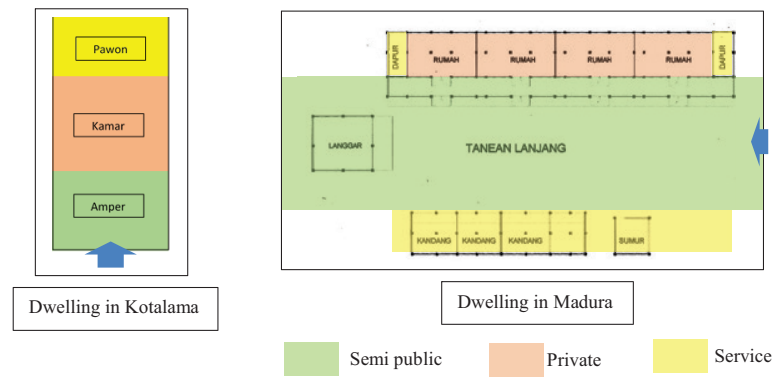

Figure 3. The personal space and space character of the dwelling
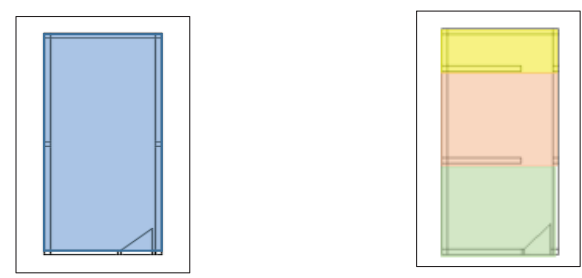

A single space / mubeng kandhang

A dwelling with some spaces

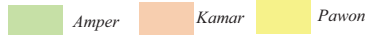

Figure 4. The Space configuration of a dwelling 
does not always have fix divisions which distinguish their functions, because the building process begins from the territorial boundary of the house and undergoes adaptation. Even though the house has not a distinct boundary between the functions of space, it accommodates all those functions. With increasing economic status, the size of each unit may not change but each function will be differentiated by a significant distinctive physical boundary. Extensions to the dwelling are usually vertical and will follow a similar process by constructing a first-floor outer boundary wall followed by spatial division. On Madura, a dwelling or house forms the main room, which has the main door. It has one bedroom with a veranda and the interior space at the back part is closed and dark. The house only has a door or a window as the opening at the facade. However, a simple house may not have any windows it is a single space without any partitions (Pangarsa et al., 1994; Tulistyantoro, 2005; Asmarani et al., 2016).

As previously described, a house in Kotalama functions as a dwelling, although some may be used for business. This is different from the traditional settlement which uses a tanean lanjheng pattern, where the house is intended for women and children to sleep in. The veranda has a halfopen wall, opening only on the front. The main function of this space is as a living room for women. Houses in Kotalama are intended for men, women, and children. They are not shaped in the tanean lanjheng form where a large family lives but form single-occupancy dwelling, inhabited one nuclear family. In addition, the limited land available for building may also influence the size and space of the dwelling.

In Kotalama, the orientation of the dwelling buildings is not in the direction of the North and South, as usually found in tanean lanjheng, but is determined by the course of the river and the existing contours. The building is oriented to the road, which extends parallel to the river or perpendicular to the river for building that back and faces the river, which built along the river. For houses, which are not located on the riverbank, the buildings are oriented to the neighboring streets.

In the adaptation process of Madurese migrants to their new neighborhood, they bring the spirit of place, which is distinctive, together with cherished aspects of place from their place of origin. Local construction workers build their own dwellings or employ laborers from Madura. As a result, the process of the formation of space tends to follow what is done by the Madurese community. Cultural values at the Kotalama are a reflection of the culture of the community, socialization, and interaction with the environment. Their identity as Madurese migrants, such as the basic character of tolerance, loyalty, trust is consistent in socialization. These territorial formed values are the basis of equality as fellow immigrants, and private space is established by building partitions between external and internal space, as in Madura Island (Asikin et al., 2016).

The configuration of dwelling space is the result of the process of interaction between Madura migrants and their environment. The space configuration begins with the formation of the mubeng kandhang which resembles the process of forming a dwelling in the tanean lanjheng pattern. The function of this enclosed space also resembles the function of the residential space of the tanean lanjheng, but differs in size.

\section{Conclusions}

Humans adapt to their environment to achieve a balance of the physical, socio-cultural and behavioral elements. Space configuration is the result of changes in space due to the interaction between these elements. The configuration of dwelling space in Kotalama is an element of adaptation in the process of the interaction between the migrants and their environment, which is different from their place of origin. The space configuration of dwellings consists of three different functions known as amper - kamar and pawon, which do not always represent physical boundaries in the space. The spirit of place, distinctive and cherished aspects of a place brought by migrant Madurese from their place of origin related to their cultural values and identity, become their space experience in the dwelling. The space configuration is also influenced by local topographical factors and limited by the size of the settlement area.

Although it is accepted that the adaptation concept consists of three elements, which are the structural, behavioral, and functional, the current study found that the space configuration of the dwelling reflects the structural aspect only. To further explore the study of adaptation elements, further studies related to behavior and functional aspects need to be conducted.

\section{Acknowledgments}

My appreciation goes to the Ministry for Research, Technology, and Higher Education of the Indonesian Republic, who provided my scholarship and the financial support for my research. I acknowledge the help of my co-authors. A special thanks to H. Moh. Holil, who was a key informant and helped with nominating other inhabitants of Kotalama who contributed to my research. Thanks also to Dr. Alan McGee for his help with the publication of this article.

\section{References}

Amorim, L., \& Loureiro, C. (2007). The space of architecture and a new conservation agenda. City \& Time, 2(3), 1.

Asikin, D., Antariksa, Wulandari, L. D., \& Rukmi, W. I. (2017). Spatial adaptation as the madurese migrant resilience form at urban informal sector workers settlement: a case study of Kotalama settlement - Malang. ICSADU IOP Conference Series: Earth and Environmental Science, 99(012027), 1-7. https://doi.org/10.1088/1755-1315/99/1/012027

Asikin, D., Antariksa, \& Wulandari, L. D. (2016, 7 December). Konservasi Spasial dan Psikologi pada Permukiman Migran Madura Kelurahan Kotalama - Malang. In Proceeding Simposium Nasional RAPI XV, 294-301. Surakarta, Indonesia.

Asikin, D. (1996). Keragaman Spasial Rumah Tinggal di Daerah Pengaliran Sungai Brantas Kelurahan Kotalama - Kotamadya Malang (Thesis). Gadjah Mada University, Yogyakarta. 
Asmarani, I. K., Antariksa, \& Ridjal, A. M. (2016) Elemen Arsitektural Rumah Bangsal di Desa Larangan Luar Pamekasan Madura. Faculty of Engineering, Brawijaya University, Malang. https://doi.org/10.24167/tes.v14i1.514

Berry, J. W. (2005). Acculturation: living successfully in two cultures. International Journal of Intercultural Relations, 29, 697-712. https://doi.org/10.1016/j.ijintrel.2005.07.013

Bott, S., Cantrill, J. G., \& Myers, O. E Jr. (2003). Place and the promise of conservation psychology. Human Ecology Review, 10(2), 100-112.

Chen, L., \& Pan, S. (2002). Cultural identification, cultural identity and communication. Intercultural Communication Studies, $X I(2)$.

Dewi, P. F. R., Antariksa, \& Surjono. (2008). Pelestarian Pola Perumahan Taneyan Lanjhang pada Permukiman di Desa Lombang Kabupaten Sumenep. Arsitektur e-Journal, 1(2), 94-109.

Jenkins, R. (1997). Rethinking Ethnicity, Arguments, and Explorations. London: Sage Publication.

Jonge, H. (1989). Madura dalam Empat Zaman: Pedagang, Perkembangan Ekonomi, dan Islam: Suatu Studi Antropologi Ekonomi. Jakarta: Gramedia.

Kabir, S. (2012). Vulnerability and adaptation practices in the settlement pattern: a case of water logged village in Keshabpur. Proceeding ICETCESD 2012, 1-21. Bangladesh: Sylhet.

Kusliansjah, K. (2015). Konsep Arsitektur Kawasan Sungai Pasang Surut pada Era Pra Kolonial dan Kolonial di Kota Lama Banjarmasin (Dissertation). Universitas Katolik Parahyangan, Bandung.

Levy-Leboyer, C. (1982). Psychology and environment. Sage Publications.

Ma'arif, S. (2015). The History of Madura; Sejarah Panjang Madura dari Kerajaan, Kolonialisme sampai Kemerdekaan. Yogyakarta: Araska Publisher.

Moleong, L. J. (2016). Metodologi Penelitian Kualitatif (edisi Revisi). Bandung: Remaja Rosdakarya.

Muhadjir, N. (1992). Metodologi Penelitian Kualitatif (edisi IV). Yogyakarta: Rake Sarasin.

Mukhlisah, Antariksa, \& Wijayanto, T. (2011). Pola Permukiman Tradisional Madura Desa Ellak Daya Kabupaten Sumenep. Prosiding Seminar Nasional "Teritorialitas, Pariwisata, Dan Pembangunan Daerah” (pp. 1-7). Denpasar: Program Studi Magister Arsitektur Universitas Udayana.
Pangarsa, G. W., Tjahjono, R., \& Pamungkas, S. T. (1994). Deformasi dan Dampak Ruang Arsitektur Madura Pedalungan di Lereng Utara Tengger. Malang: Fakultas Teknik Universitas Brawijaya.

Reyes-García, V., Balbo, A. L., Gómez-Baggethun, E., Gueze, M., Mesoudi, A., Richerson, P. J., Rubio-Campillo, X., RuizMallén, I., \& Shennan, S. (2016). Multilevel processes and cultural adaptation: examples from past and present smallscale societies. Ecology and Society, 21(4), 2. https://doi.org/10.5751/ES-08561-210402

Reynoso, L. G. D., Kobayashi, H., Morinaga, R., Jung, J., \& Tarvainen, T. (2016). Urban adaptation in dwelling patterns in an informal settlement in the Dominican Republic - A case study of Azul in San Francisco de Macorís. Journal of Asian Architecture and Building Engineering JAABE, 15(1), 95-102. https://doi.org/10.3130/jaabe.15.95

Ridjal, A. M. (2014). Perubahan Fungsi Ruang Taneyan Lanjhang pada Masyarakat Migran Madura di Desa Krajan Jember. Jurnal RUAS, 12(2), 69-78.

https://doi.org/10.21776/ub.ruas.2014.012.02.7

Scannell, L., \& Gifford, R. (2010). Defining place attachment: A tripartite organizing framework. Journal of Environmental Psychology, 30, 1-10. https://doi.org/10.1016/j.jenvp.2009.09.006

Schultz, N. (2009). Theory of occupational adaptation (11th ed.). Philadelphia: Lippincott Williams \& Wilkins.

Smith, D. (1990). Introduction: the sharing and dividing of geographical space. Shared Space, Divided Space: Essays on Conflict and Territorial Organization, 1-21. London: Unwin Hyman.

Syamsudin, M. (2007). Agama, Migrasi dan Orang Madura. Aplikasia Jurnal Aplikasi llmu-ilmu Agama, VIII(2), 150-182.

Susanto, E. (2008). Ruh Islam dalam "Wadag" Lokal Madura: Kasus "Tanean Lanjeng”. KARSA, XIV(2), 142-147.

Taufiqurrahman. (2007). Identitas Budaya Madura. KARSA, $X I(1), 1-11$.

Tulistyantoro, L. (2005). Makna Ruang pada Tanean Lanjang di Madura. Dimensi Interior, 3(2), 137-152.

Ubaidillah, K. (2014). Dinamika Perantau Madura dalam Politik Kota Malang (Suatu Kajian Antropologi Politik). Yogyakarta: Gadjahmada.

Wiyata, A. L. (2013). Mencari Madura. Jakarta: Bidik-Phronesis Publishing. 